\title{
Editorial
}

\section{Best Papers Introduction}

\author{
Douglas D. Archbold
}

Citation: Archbold, D.D. Best Papers Introduction. Horticulturae 2021, 7, 186. https://doi.org/10.3390/ horticulturae7070186

Received: 21 June 2021

Accepted: 28 June 2021

Published: 7 July 2021

Publisher's Note: MDPI stays neutral with regard to jurisdictional claims in published maps and institutional affiliations.

Copyright: (C) 2021 by the author. Licensee MDPI, Basel, Switzerland. This article is an open access article distributed under the terms and conditions of the Creative Commons Attribution (CC BY) license (https:/ / creativecommons.org/licenses/by/ $4.0 /)$.
Department of Horticulture, University of Kentucky, N318 Agricultural Sciences North, Lexington, KY 40546, USA; darchbol@uky.edu

I am pleased to draw attention to two papers published in Horticulture in 2019 which the Editorial Board has recognized as worthy of special attention as "Best Papers of 2019", among the many excellent papers from that year. They are both noteworthy publications which have generated significant interest in the horticultural sciences community.

These papers are:

"Recent Advances in Hormonal Regulation and Cross-Talk during Non-Climacteric Fruit Development and Ripening." 2019. Fuentes, L., Figueroa C.R., Valdenegro, M.

"Evaluation of Two Wild Populations of Hedge Mustard (Sisymbrium officinale (L.) Scop.) as a Potential Leafy Vegetable." 2019. Guarise, M., Borgonovo, G., Bassoli, A., Ferrante, A.

Fuentes et al. have published an extensive review on the potential involvement of plant hormones in the ripening of non-climacteric fruit [1]. These types of fruit have been a much greater challenge to manage in the postharvest chain compared to climacteric fruit. They discuss the similarities between the ripening types, especially their quality changes. The concept that plant hormones may control non-climacteric fruit ripening has evolved over the years, and they review the literature covering what has been established about the involvement of abscisic acid, indoleacetic acid, ethylene, gibberellins, cytokinin, brassinosteroids, and jasmonates in non-climacteric ripening. In addition, they present a review of studies on hormonal crosstalk among these phytohormones in the ripening process. Grape, strawberry, and raspberry are presented as models/examples of non-climacteric fruit, and these are compared and contrasted to one another and to the climacteric model. They conclude that the molecular dissection of these non-climacteric fruit models has shown that various phytohormones may act together or regulate each other to affect several molecular and biochemical processes that contribute to fruit quality at the onset of ripening. They also note that the growing body of information on the identification and characterization of key genes associated with the signaling and perception of these hormones, most notably in grape and strawberry, could widen our knowledge of the ripening of other non-climacteric fruit species, and contribute to improving strategies for postharvest quality maintenance and food security.

Guarise et al. have published an original study on the possible use of hedge mustard (Sisymbrium officinale (L.) Scop.) as a new leafy green crop [2]. They note that the significant growth in production and consumer interest in minimally processed leafy greens has been accompanied by changes in production systems to the greater use of protected culture and unique substrates, away from traditional field culture. The introduction of new species can be useful for diet enrichment and crop diversification. Hedge mustard has been a traditional medicinal plant that belongs to the Brassicaceae family. They evaluated its production potential for spring and fall in a commonly used system for leafy greens, in a peat substrate in a greenhouse, and measured a number of quality attributes including carotenoids, phenolics, anthocyanins, and ascorbic acid. They demonstrated that hedge mustard can be successfully grown in a greenhouse and has desirable nutritional components. Its nutritional aspects were similar to other leafy vegetables, but its lower nitrate and higher ascorbic acid concentrations may make it preferable to some consumers over other leafy crops. Because no breeding work has yet been done with hedge mustard, it has unknown 
but perhaps great potential to add to the list of leafy greens that growers can offer to consumers.

Conflicts of Interest: The author declare no conflict of interest.

\section{References}

1. Fuentes, L.; Figueroa, C.R.; Valdenegro, M. Recent Advances in Hormonal Regulation and Cross-Talk during Non-Climacteric Fruit Development and Ripening. Horticulturae 2019, 5, 45. [CrossRef]

2. Guarise, M.; Borgonovo, G.; Bassoli, A.; Ferrante, A. Evaluation of Two Wild Populations of Hedge Mustard (Sisymbrium officinale (L.) Scop.) as a Potential Leafy Vegetable. Horticulturae 2019, 5, 13. [CrossRef] 